Man and Nature

L'homme et la nature

\title{
Bourgeois Morality and Aristocratic Libertinism in the Comédie Larmoyante of La Chaussée
}

\section{Hope Leith}

Volume 8, 1989

URI : https://id.erudit.org/iderudit/1012592ar

DOI : https://doi.org/10.7202/1012592ar

Aller au sommaire du numéro

Éditeur(s)

Canadian Society for Eighteenth-Century Studies / Société canadienne d'étude du dix-huitième siècle

ISSN

0824-3298 (imprimé)

1927-8810 (numérique)

Découvrir la revue

Citer cet article

Leith, H. (1989). Bourgeois Morality and Aristocratic Libertinism in the

Comédie Larmoyante of La Chaussée. Man and Nature / L'homme et la nature, 8 ,

9-15. https://doi.org/10.7202/1012592ar

Copyright (c) Canadian Society for Eighteenth-Century Studies / Sociéte canadienne d'étude du dix-huitième siècle, 1989
Ce document est protégé par la loi sur le droit d'auteur. L'utilisation des services d’Érudit (y compris la reproduction) est assujettie à sa politique d'utilisation que vous pouvez consulter en ligne.

https://apropos.erudit.org/fr/usagers/politique-dutilisation/ 


\section{Bourgeois Morality and Aristocratic Libertinism in the Comédie Larmoyante of La Chaussée}

The name Nivelle de La Chaussée evokes, if anything, a vague and distant memory of plays with implausibly virtuous heroines and excessively noble rhetoric, and a controversy over changing the traditional limits of comedy which was taken up by Diderot and Mercier. It seems quite inappropriate to apply the term 'libertine' to La Chaussée or to his work, especially if one recalls any of the numerous epigrams directed at them, such as Colle's reference to a promised new sermon by the Reverend Father La Chaussée for which all the seats have been reserved. ${ }^{1}$ This criticism, from rivals jealous of his success and his early appointment to the Académie française, did not impede the sentimental pleasure of his audience:

Aucune de ces injures, soit ingénieuses, soit insipides, n'empêcha les pièces qui en étaient l'objet d'être suivies et même très-goûtées. On riait un moment ... et on retournait pleurer au Préjugé à la mode et à Mélanide. ${ }^{2}$

Yet close examination, which La Chaussée rarely receives, can justify the application of 'libertine' not only to his private life but also to certain aspects of his comédies larmoyantes.

La Chaussée is now usually considered a minor playwright, given a paragraph in the standard histories as a necessary if tedious precursor of Diderot and the drame bourgeois, and brushed aside. His plays are held to express the moral values of the rising bourgeoisie: 'Le bourgeois prend le devant de la scène et exhibe avec emphase et bonne conscience l'image édifiante qu'il entend donner de sa classe. ${ }^{3}$ Reading one of his plays, even the very popular Préjugé à la mode or La Gouvernante, only confirms this summary judgement. The vocabulary and style of expression mix pretentious maxims with sighs and dramatic exclamations:

Dis-moi ... Qu'est devenue une épouse si chère?

$\mathrm{Ah}$ ! je suis son bourreau plutôt que son époux. (Durval, Le Préjugé; $\mathrm{V}, \mathrm{i}$ ) Que l'amour-propre abonde en mauvaises défaites,

Quand il faut réparer les fautes qu'on a faites!

(Damon, op.cit.; V, ii) ${ }^{4}$ 
The plots are tangled and 'romanesque,' full of misunderstandings, concealed identities, and recognition scenes, like the popular novels of the period (La Vie de Marianne, Pamela, Clarissa). The comic elements are reduced or eliminated to make room for the sufferings and eventual reward of virtue, generally female. All the classical conventions are scrupulously maintained: five acts, verse rather than prose, unity of time and place, rigid decorum. To the modern reader, these plays can seem like melodrama escalated to the point of farce; one has to recall that they provoked tears of sympathy rather than of hilarity: 'Il est bien évident que ce caractère de fadeur ne déroutait pas le spectateur, encore moins lui donnait-il envie de sourire.' (Descotes, p. 206) We must remember that La Chaussée won considerable acclaim for his plays, some of which survived in the repertory of the Comédie française for close to a hundred years, and was taken seriously as a dramatist until at least the end of the eighteenth century. ${ }^{5}$

Closer examination throws into relief the didactic rather than purely sentimental nature of the plays, and also the ambiguity of the ideology they conveyed. French theatre had long had the tradition of teaching as well as entertaining. What changes in La Chaussée is first the method of entertaining. It becomes l'attendrissement, an appeal to the emotions rather than to the sense of humour. In this La Chaussée reflects the beliefs of this period. This love of 'sensibilité' came into fashion at the end of the seventeenth century, but grew in popularity during and after the Regency. As a phenomenon it has many generic explanations, but for our purposes we can agree with Jourdain that it is based on a loose reading of Locke's sensation theory in philosophy, and led to a sentimental view of the passions, weakening the old duty-based morality as found in Racine and Corneille. ${ }^{6}$ Any act could be defended as moral as long as it expressed 'sensibilité' and kindness of heart:

Sensibilité et vertu se confondent; les larmes ne sont que la manifestation extérieure de la bonté d'âme. (Descotes, p. 204)

Le plaisir se confond avec la vertu et la morale. ${ }^{7}$

A well-known example of this 'new morality' is Manon Lescaut, in which the Chevalier and Manon, however libertine their conduct, are perceived as sympathetic characters, even pardoned for their sins and faults, because they feel so intensely. The popularity of such sentimental novels as La Vie de Marianne, Le Doyen de Killerine, and Pamela prepared the way for La Chaussée's plays and contributed to their success:

Le théâtre de La Chaussée est tout entier un théâtre d'amour; les gens des loges viennent s'y attendrir, comme ils pleurent à la lecture des romans. ${ }^{8}$ 
Il n'est pas de succès possible sans l'étalage de cette vertu, attendrissante, pour une époque qui se délecte aux romans de l'abbé Prévost ou de Marivaux. (Descotes, p. 205)

Women played an important role in this fashion for 'sensibilité', as symbols of pure, natural feeling as opposed to male rationality and cynicism. But this also often made them victims of men, as in Clarissa. Sensibility and true virtue were held to be natural well before Rousseau, and were presented as contrary to the shallowness of learned virtues, which is a useful argument against the education of women (Jourdain, p. 73). La Chaussée's theatre focusses on precisely that female sensibility. His plays are built around heroines like Mélanide, the gouvernante, Mme Argant and her daughter Marianne in L'Ecole des mères, and Constance in Le Préjugé, women of intense emotions rather than clear thinking.

Love is the mainspring of all these plays, love within marriage, between lovers who will marry, and between parents and children. La Chaussée presents the belief that affection and duty are inseparable in Mélanide $(\mathrm{V}$, iii) and L'Ecole des mères $(\mathrm{V}, \mathrm{x})$. He uses the truism that 'blood tells' as a plot device, to permit recognition scenes and immediate expression of affection between a parent and a child who have never seen each other before (Mélanide; $\mathrm{V}$, iii), or not since the child was two (L'Ecole des mères; $\mathrm{V}, \mathrm{ix})$. The restoration of affective ties is more important in La Chaussée's theatre than the formation of new ones. In L'Ecole des mères, the reunion of Marianne with her mother is emphasized over her marriage with Doligni fils. In Mélanide the reuniting of the longseparated spouses, Mélanide and the Marquis, and the acknowledgement of Darviane as the Marquis' son, overshadow the love affair between Darviane and Rosalie. This is the traditional view of La Chaussée, as a bourgeois playwright, proclaiming the value of fidelity and family. Indeed, on the surface, La Chaussée seems a clear precursor of Diderot and Rousseau in his attitudes towards women and the family.

But the plays also demonstrate clear traces of the libertinism of La Chaussée's youth during the Regency, which he never abandoned in his later private life. La Chaussée was one of the few eighteenth-century French playwrights to move in the highest society. His family belonged to the noblesse de robe, boasted a number of fermiers-généraux and was related to the old nobility, the d'Hérouvilles. ${ }^{9}$ His earliest works are verse tales and a farce, writings that are far from virtuous, composed in the twenties for an exclusive circle of friends: the comte de Livry, the Chevalier du Temple, a natural son of the Regent, and the comte de Clermont, a prince $d u$ sang (Lanson, pp. 7-15). In his private life, the playwright can best be described as a rake; Lanson calls him 'un 
méchant'. He never married, but kept a series of mistresses, from wellborn ladies to fourteen-year-old servant girls (Lanson, pp. 3-5). He died in his discreet 'petite maison' with the last 'infante' (Lanson, p. 39).

In L'Ecole des mères, the daughter, Marianne, is presented as the niece and then as the mistress of her father, giving the titillation of implied incest to the plot without actually violating the 'bienséances.' The son, a would-be aristocratic libertine, is consistently ridiculed for his vanity, extravagance, and unsuccessful attempts at seduction. The traditional view is that La Chaussée is criticizing aristocratic behavior and praising bourgeois values, as in Bernard's 1982 introduction to her edition of this play. But, with the knowledge that La Chaussée in fact lived his own life according to the code which the son in $L^{\prime} E c o l e$ tries to follow, the ridicule seems more that of an aristocrat towards the parvenu, the bourgeois who wants the title and the lifestyle of a nobleman but succeeds only in being duped. There is also a critique in $L^{\prime} E$ cole of the bourgeois preoccupation with business in the person of M. Argant, who neglects his role as husband and father to add to his fortune in land (II, iv and vi), a preoccupation exemplified in Doligni père's frankly commercial attitude to marriage:

(fils) Mais je ne connois point mademoiselle Argent.

(père) Ni moi; mais elle aura vingt mille écus de rente. (I, i)

An aristocrat might well be as mercenary, but he would not be so crude.

The plot of Mélanide concerns an illicit liaison which occurred eighteen years before the play begins, between Mélanide and the Marquis, which produced an illegitimate child, Darviane. Darviane and the Marquis, father and son, court the same girl, Rosalie. Using these lessthan-virtuous situations, the play criticizes the tyranny of arranged marriages and family authority taken to the extreme. We must keep in mind that divorce generally speaking was impossible in France of the Ancien Régime, separation difficult, but the annulment of a marriage made without consent of guardians, like that between Mélanide and the Marquis, was perfectly straightforward. The type of marriage suggested by La Chaussée is more like an affair, with the man treating his wife like a mistress: with affection and fidelity. Achievement of this type of marriage forms as well the whole plot of Le Préjugé. La Chaussée also seems to argue here against the stigma on illegitimate children. It must be noted that Mélanide and the Marquis are never legally married, not when they conceive Darviane and not when the Marquis acknowledges him as his son and is reunited with Mélanide as her 'époux' $(\mathrm{V}, \mathrm{iii})$. 
Despite the critical tradition, La Chaussée's theatre is arguably no more 'bourgeois' than that of Marivaux, for example, or of Voltaire, or even Sedaine. They all argue for marriages of affection rather than of interest or convenience, love rather than command between parents and children. But they all stop short of rejecting aristocratic values; the bourgeois is present on stage but not in the spotlight. ${ }^{10}$ There is little class mobility in La Chaussée, and little tolerance for social ineptness. The son in L'Ecole, while not too low-born to aspire to social standing, is too easily duped ever to be a successful libertine. Neither the Marquis in Mélanide nor the mother in L'Ecole reform out of a conviction of moral duty, but rather out of a realization that their greater happiness lies in reconciliation:

O Ciel! tu me fais voir, en comblant tous mes voeux,

Que le devoir n'est fait que pour nous rendre heureux. (Mélanide; V, iii)

One is reminded of Mlle Habert in Le Paysan parvenu, delighted to be as happy without sin in marriage as the sinners are. ${ }^{11}$

La Chaussée did not write for a living; his private income was sufficient for his needs. This independence from publishers and patrons sets him even further apart from other writers of his time (d'Alembert, p. 391). He wrote for that truly aristocratic and libertine motive la gloire, to make a name for himself in society as Voltaire did with Oedipe. He began to write under the Regency, with a knowledge of and a deep respect for the Classical traditions expressed by Boileau and Racine (Jourdain, p. 64). To call him a bourgeois playwright is not only incorrect but misleading. His characters are never truly bourgeois; many have titles. The values presented are those fashionable in Parisian society, the 'sensibilité' of a literate, leisured, and hedonistic class which considered virtue a means to greater happiness, as the Marquis in Mélanide does. The adjective may apply only if we redefine 'bourgeois' as this society - haute bourgeoisie, noblesse de robe, petty nobility - beneath the court nobility but well above the actual working class.

According to Lanson (pp. 292-5), the standard literary heritage of La Chaussée is in the drame of Diderot and later of Scribe, Augier, and Dumas, and also in the melodrama, a view still upheld by Lioure. ${ }^{12}$ But we see the same virtuous sensiblity, the same 'naturally' good woman in a position of weakness and victimization, in an undeniably libertine or at least anti-sentimental work such as Laclos' Les Liaisons dangereuses or de Sade's Les Infortunes de la vertu. Traditional criticism appears to ignore the libertine undertones in La Chaussée. He advocates freedom and affection in sexual relationships, as we would expect 
from a Regency libertine. ${ }^{13}$ Nonetheless, he can be seen as encouraging the sort of female sensibility which is so cruelly abused and mocked in Laclos and de Sade. To La Chaussée, women should be patient victims who will be rescued eventually by men, whereas Laclos and de Sade grant the virtue but deny the possibility of a happy ending. The essential difference between, for example, Mélanide and the présidente de Tourvel lies not in their own natures, which are very similar, but in the character of their lovers. The Marquis has a 'better nature' which overcomes his desire for Rosalie, and leads him to acknowledge Mélanide and Darviane. Valmont's 'better side' does not reveal itself until too late for the présidente.

La Chaussée's plays should not be written off as a passing 18thcentury fad. The popularity of his theatre, with its implied libertinism, indicates that the tastes and standards of Paris society were no more bourgeois and virtuous in 1735 when Le Préjugé appeared than in 1784 on the publication of Les Liaisons dangereuses. Indeed, the registers of the Comédie française, as presented by Lough (1951), indicate a resurgence rather than a decline in popularity for La Chaussée's plays in the late eighteenth century. Traditional criticism of La Chaussée's plays often skims over both their success and their ambiguity. It seems more just and more interesting to study him in order to better understand French society in the mid- to late-eighteenth century, a society that seemed to enjoy virtue vicariously instead of practising it:

Au scandale et à la licence de la régence succède le sérieux ... que Destouches et La Chaussée ont appelé à la scène. Mais il ne faut pas croire que le siècle en avançant se soit corrigé ... . On finit par se lasser même de l'indécence, et l'ennui porte à la vertu. ${ }^{14}$

And that by its own vogue for perfect sentimental heroines provoked the relentless anti-sentimentality of Laclos and de Sade: 'La surproduction des hérö̈nes intouchables dans la lignée richardsonienne préparent les orgies charnelles d'un Restif ou d'un Sade. ${ }^{\prime 15}$ What is less often recognized is the role of a sentimental playwright (rather than novelist) like La Chaussée in presenting this kind of heroine for admiration and possible imitation, and in demonstrating the compatibility of virtue with libertinism and hedonism. The considerable success of $\mathrm{La}$ Chaussée in the 18th century indicates the need for further study on his probable social and literary influence.

HOPE LEITH

University of British Columbia 


\section{Notes}

1 M. Descotes, Le Public du théâtre et son histoire (Paris: PUF, 1964), p. 192.

2 d'Alembert, 'Eloge de Nivelle de La Chaussée,' Oeuvres (Geneva: Slatkine, 1967), tome III, p. 394.

3 I. Bernard, introduction to L'Ecole des mères by Nivelle de La Chaussée (Geneva: Droz, 1982), p. 17.

4 Nivelle de La Chaussée, Le Préjugé à la mode in Répertoire du théâtre françois (Paris: Foucault, 1817), tome 13, p. 116. All quotations from La Chaussée's plays will be taken from this volume.

5 J. Lough, 'La Comédie Française 1701-1774. Plays, Actors, Spectators, Finances,' Transactions of the American Philosophical Society 41:4 (1951): 593-849.

6 E. Jourdain, Dramatic Theory and Practice in France 1690-1808 (London: Longmans, Green, 1921), p. 73.

7 P. Trahard, Les Maîtres de la sensibilité française (Paris: Boivin, 1932), tome II, p. 22.

8 H. Lagrave, Le Théâtre et le public à Paris de 1715 à 1750 (Paris: Klincksieck, 1972), p. 506.

9 G. Lanson, Nivelle de La Chaussée et la comédie larmoyante (Paris: Hachette, 1887), pp. 1-2.

10 In this regard see Haydn Mason, 'le Philosophe sans le savoir: An Aristocratic Drame bourgeois?' French Studies 30 (1976) : 405-18.

11 Marivaux, Le Paysan parvenu in Romans (Paris: Editions de la Pléiade, 1949), pp. 772-3.

12 M. Lioure, Le Drame de Diderot à Ionesco (Paris: Armand Colin, 1973), pp. 53 and 175.

13 E. Sturm, Crébillon fils et le libertinage au dix-huitième siècle (Paris: Nizet, 1970), pp. $98-100$.

14 R. Nicklaus, 'La Propagande philosophique au théâtre au siècle des lumières,' SVEC XXVI (1963), p. 1244.

15 P. Fauchery, La Destinée féminine dans le roman européen du dix-huitième siècle 1713-1807 (Paris: Armand Colin, 1972), p. 840.

16 As an indication of his popularity, I have found five 18th-century editions of his complete works, fifteen editions of Le Préjugé, six of $L ' E c o l e$, eight of Mélanide, and eleven of La Gouvernante, as well as translations into Italian, German, Dutch, and Spanish: Catalogue général de la Bibliothèque Nationale, British Museum Catalogue, National Union Catalogue.

I must also thank Dr. Seymour Feiler of the University of Oklahoma for allowing me to read a first draft of an unpublished paper, 'Nivelle de la La Chaussée: Eighteenth-Century Feminist,' although I do not wholly accept his conclusions, and Dr. Laurence L. Bongie for his very useful advice and criticism on the first draft of this paper. 